\title{
Significance of Interleukin-6 in Papillary Thyroid Carcinoma
}

\author{
Toral P. Kobawala, Trupti I. Trivedi, Kinjal K. Gajjar, Darshita H. Patel, \\ Girish H. Patel, and Nandita R. Ghosh
}

Division of Molecular Endocrinology, Cancer Biology Department, The Gujarat Cancer \& Research Institute, NCH Compound, Asarwa, Ahmedabad, Gujarat 380016, India

Correspondence should be addressed to Nandita R. Ghosh; nandita.ghosh@gcriindia.org

Received 29 October 2015; Accepted 17 February 2016

Academic Editor: Noriyuki Koibuchi

Copyright (C) 2016 Toral P. Kobawala et al. This is an open access article distributed under the Creative Commons Attribution License, which permits unrestricted use, distribution, and reproduction in any medium, provided the original work is properly cited.

\begin{abstract}
This study sought to reveal the significance of IL-6 in papillary thyroid carcinoma by determining its circulating levels, tumoral protein, and mRNA expressions. As compared to the healthy individuals, serum IL-6 was significantly higher in patients with benign thyroid diseases and PTC. Further, its level was significantly higher in PTC patients as compared to patients with benign thyroid diseases. ROC curves also confirmed a good discriminatory efficacy of serum IL- 6 between healthy individuals and patients with benign thyroid diseases and PTC. The circulating IL-6 was significantly associated with poor overall survival in PTC patients. IL-6 immunoreactivity was significantly high in PTC patients as compared to the benign thyroid disease patients. Significantly higher IL-6 mRNA expression was also observed in the primary tumour tissues of PTC patients than the adjacent normal tissues. The protein expression of IL- 6 at both the circulating and tissue level correlated with disease aggressiveness in PTC patients. Moreover, a significant positive correlation was observed between the IL-6 protein and mRNA expression in the primary tumours of PTC patients. Finally in conclusion, IL- 6 has an important role in thyroid cancer progression. Thus targeting IL- 6 signalling can help in clinical management of thyroid carcinoma patients.
\end{abstract}

\section{Introduction}

IL-6 is apleiotropic cytokine having a central role in the regulation of inflammatory and immune responses [1]. It is secreted by different cell types including macrophages, $\mathrm{T}$ and B lymphocytes, fibroblasts, endothelial cells, and cancer cells [2]. It was cloned in 1986 as the B-cell differentiation factor [3].

IL-6 has been known to exert its biological activities through binding to its receptors and further leads to activation of signal transduction via various pathways like: janus kinase/signal transducers and activators of transcription (JAK/STAT), phosphatidylinositol 3' kinase/Akt (PI3K/Akt), and mitogen activated protein kinase (MAPK) pathway [4]. Numerous studies indicate that IL- 6 and its related signalling pathways have been identified to contribute to proliferation, migration, and invasion of various tumour cells [5-9] and its expression is associated with poor prognosis in many types of cancers [10-12]. Moreover, the physiological role of IL-6 has been shown to promote not only tumour proliferation, but also metastasis and symptoms of cachexia $[6,13,14]$. Increased expression of IL- 6 has been reported in different types of cancers and high serum levels of IL- 6 have been associated with metastasis and unfavourable prognosis [2, 15-17]. Further, possible involvement of IL-6 signalling in the resistance to chemotherapy and radiotherapy has been documented in few studies [18-20]. Regarding its therapeutic role, blockade of IL- 6 in the various autoimmune and inflammatory diseases, by tocilizumab, a humanized anti(human IL-6R) monoclonal antibody, has proved to improve symptoms of rheumatoid arthritis, Castleman's disease, and systemic juvenile idiopathic arthritis [21]. IL-6 signalling has also been investigated as a potential target for several types of cancer therapies $[22,23]$.

Thyroid cancer is the most common and slowly progressing endocrine malignancy, accounting for less than $1 \%$ of malignancies diagnosed. Although survival is generally good, the mortality rate is higher than all other endocrine organ cancers. It was estimated that 6 out of every 1 million people die due to thyroid cancer. About $85 \%$ of thyroid 
cancers are papillary thyroid cancer (PTC). Despite high survival rates, local recurrence and metastases may occur in some patients and this may require a more aggressive surgical treatment [24]. Moreover, an association between the thyroid cancer and a history of underlying inflammatory conditions of benign diseases has been evident from the literature. Besides this, very often, a pathologist is confronted with thyroid lesions in which the distinction between benign and malignant can be rather difficult and as a result, the decision supporting one or another has clinical consequences and implies different treatment modalities. Thus, it was hypothesised that IL-6, a proinflammatory cytokine, and one of the chief components of the underlying inflammatory conditions, may help in differential diagnosis of thyroid diseases.

Thus, the goal of this study was to examine the role of IL-6 in benign and papillary thyroid cancer patients and correlate the results with clinicopathological parameters and disease outcome of PTC patients. To achieve this aim, we assessed the circulating levels of IL- 6 in both patients with benign thyroid diseases and PTC and compared with healthy individuals. We further studied the protein expression of IL- 6 in the primary tumours of PTC patients in relation to the benign tissues and also determined its mRNA expression in the primary tumour as well as adjacent normal tissues of histologically confirmed PTC patients.

\section{Materials and Methods}

2.1. Patients. Sixty-seven patients with benign thyroid diseases and 83 pathologically confirmed PTC patients were included in this study. This patient group and their clinicopathological features shown in Table 1 are same as mentioned previously [25]. Forty-five out of 67 benign thyroid disease patients underwent surgery at our institute and were included for immunohistochemical analysis. The WHO classification and the AJCC/UICC TNM staging system were used to histopathologically classify the tumours and to stage the thyroid cancer patients, respectively. Accordingly, the patients were grouped into younger ( $<45$ years) and elder ( $\geq 45$ years) age groups. All patients were followed for a period of 4 years or until death within that period. Complete followup details were obtained in 92\% (76/83) PTC patients and were included for overall survival (OS) analysis. Nine percent (7/76) patients amongst these had persistent disease and hence were not included for the disease free survival (DFS) analysis. Therefore, 69/76 PTC patients were included for DFS analysis. IL- 6 mRNA was determined in the primary tumour and adjacent normal tissues of sixty PTC patients. With respect to IL-6 mRNA expression, DFS was evaluated in 54/60 PTC patients as the rest of six patients had persistent disease and hence were not included for the DFS analysis, while all sixty patients were included for OS analysis.

2.2. Sample Collection. This study has been approved by Institutional Scientific and Ethical Committees and informed consent was obtained from all patients prior to sample collection. To detect the circulating levels of IL-6, pretherapeutic blood samples were collected from all patients as well as from 67 healthy individuals. Serum was separated after centrifugation and was preserved at $-80^{\circ} \mathrm{C}$ until analysis. Primary tissue samples of patients were collected on ice directly from the operation theatre. Both tumour and adjacent normal tissue were selected by a pathologist and divided into two portions. One portion was submitted for routine histopathological evaluation and the other portion was snap frozen in liquid nitrogen and preserved at $-80^{\circ} \mathrm{C}$ for total RNA extraction. For Immunohistochemistry, paraffin embedded tissue blocks of all the patients (who underwent surgery) were retrieved from the Histopathology Department of our institute. The clinical and histopathological details of the patients were noted from the case files maintained at the Medical Record Department of the institute.

\subsection{Circulating Levels of IL-6 by Enzyme Linked Immunosor-} bent Assay (ELISA). The circulating levels of IL-6 were estimated from the serum samples using commercially available ELISA kit from Krishgen Biosystems following manufacturer's instructions. The unknown concentrations were interpreted from the standard curve generated in Graphpad prism 5 software.

2.4. Tumoral Protein Expression of IL-6 by Immunohistochemistry (IHC). Immunohistochemical staining was performed for detection of tumoral expression of IL-6 in primary tumours of PTC patients and in patients with benign thyroid diseases. Briefly, 3-5 $\mu \mathrm{m}$ thick sections were cut from the formalin fixed paraffin embedded tissue blocks using Leica microtome and mounted on APES coated glass slides. The immunohistochemical staining was carried out using primary mouse monoclonal IL-6 antibody from R\&D Systems (MAB2061) and MACH4 Universal HRP-Polymer Detection System from Biocare Medicals, USA, as per manufacturer's protocol recommendations. Antigenicity was retrieved by heating the sections in $10 \mathrm{mM}$ sodium citrate buffer $(\mathrm{pH}$, 6.0) for 20 mins in a pressure cooker prior to application of the primary antibody. All the sections were scored independently by two individual observers in a blinded fashion. A semiquantitative Immunoreactive Score (IRS) method of Remmele and Stegner [26] based on staining positivity and staining intensity was implemented. Staining positivity was scored as 0 for no stained cells, 1 for staining in $1 \%$ to $10 \%$ of cells, 2 for staining in $11 \%$ to $50 \%$ of cells, 3 for staining in $50 \%$ to $80 \%$ of cells, and 4 for staining in $>80 \%$ of cells. The staining intensity was scored as 0 for no staining, 1 for weak/faint staining, 2 for moderate staining, and 3 for intense/dark staining. The IRS score was then obtained by multiplying the staining positivity and the staining intensity and therefore, theoretically the scores could range from 0 to 12 . For statistical evaluation, the median IRS in the two subgroups of patients was used as cut-off value to divide the patients into low ( $\leq$ median IRS) and high (>median IRS) expression groups, respectively.

2.5. IL-6 mRNA Expression by Reverse TranscriptasePolymerase Chain Reaction (RT-PCR). The total RNA was 
TABLE 1: Clinicopathological characteristics of PTC patients.

\begin{tabular}{|c|c|c|c|}
\hline Characteristics & $N(\%)$ & Characteristics & $N(\%)$ \\
\hline Age & & Bilaterality & \\
\hline$<45$ years & $41(49)$ & Unilateral & $61(74)$ \\
\hline$\geq 45$ years & $42(51)$ & Bilateral & $22(26)$ \\
\hline Gender & & Hemorrhagic area & \\
\hline Female & $56(68)$ & Absent & $72(87)$ \\
\hline Male & $27(32)$ & Present & $11(13)$ \\
\hline Tumour size & & Necrosis & \\
\hline $\mathrm{T} 1(N=16)+\mathrm{T} 2(N=22)$ & $38(46)$ & Absent & $67(81)$ \\
\hline $\mathrm{T} 3(N=30)+\mathrm{T} 4(N=15)$ & $45(54)$ & Present & $16(19)$ \\
\hline Nodal status & & Calcification & \\
\hline Absent & $30(36)$ & Absent & $32(39)$ \\
\hline Present & $53(64)$ & Present & $51(61)$ \\
\hline Metastasis & & Extrathyroidal extension & \\
\hline Absent & $73(88)$ & Absent & $52(63)$ \\
\hline Present & $10(12)$ & Present & $31(37)$ \\
\hline Stage & & Fibrosis & \\
\hline Early [stage I $(N=37)+$ stage II $(N=12)]$ & $49(59)$ & Absent & $61(74)$ \\
\hline Advanced [stage III $(N=11)+$ stage IV $(N=23)$ ] & $34(41)$ & Present & $22(26)$ \\
\hline Lymphatic permeation & & Inflammation & \\
\hline Absent & $67(81)$ & Absent & $46(55)$ \\
\hline Present & $16(19)$ & Present & $37(45)$ \\
\hline Vascular permeation & & Differentiation & \\
\hline Absent & $74(89)$ & Well & $76(92)$ \\
\hline Present & $09(11)$ & Moderate/poor & $07(08)$ \\
\hline Capsular invasion & & Multifocality & \\
\hline Absent & $55(66)$ & Absent & $64(77)$ \\
\hline Present & $28(34)$ & Present & $19(23)$ \\
\hline Encapsulation & & Residual disease & \\
\hline Well encapsulated & $76(92)$ & Absent & $24(29)$ \\
\hline Partially/not encapsulated & $07(08)$ & Present & $59(71)$ \\
\hline & eatment & & \\
\hline Surgery & $29(35)$ & & \\
\hline \multirow[t]{2}{*}{ Surgery + RIA and/RT } & \multirow[t]{2}{*}{$54(65)$} & Surgery + RIA & $50(60)$ \\
\hline & & Surgery + RIA + RT & $04(05)$ \\
\hline \multicolumn{4}{|c|}{ Disease status } \\
\hline Recurrence/distant metastasis $(N=69)$ & & Alive/dead $(N=76)$ & \\
\hline Absent & $62(90)$ & Alive & $68(89)$ \\
\hline Present & $07(10)$ & Dead & $08(11)$ \\
\hline Recurrence & $3(4)$ & & \\
\hline Distant metastasis & $4(6)$ & & \\
\hline Bone & $1(1.5)$ & & \\
\hline Lung & $2(3.0)$ & & \\
\hline Bone + lung & $1(1.5)$ & & \\
\hline
\end{tabular}

extracted by guanidine thiocyanate-phenol-chloroform extraction method modified from that by Chomczynski and Sacchi [27] and quantitated spectrophotometrically at $260 \mathrm{~nm}$ and $280 \mathrm{~nm}$ (Helios $\alpha$, Thermo Spectronic, UK). The integrity of the RNA was confirmed by on $1.4 \%$ agarose gel. RT-PCR was performed using the OneStep RT-PCR kit (Qiagen, USA) to amplify IL-6 mRNA. Primers 5' -ATG TAG
CCG CCC CAC ACA GA-3' (sense) and 5'-GCA TCC ATC TTT TTC AGC CAT C-3' (antisense) were used to amplify a 191 bp fragment specific for IL-6. The housekeeping GAPDH mRNA was used as an internal control. Primers $5^{\prime}-\mathrm{CGG}$ AGT CAA CGG ATT TGG TCG TAT-3' (sense) and 5'-AGC CTT CTC CAT GGT GGT GAA GAC-3' (antisense) were used to amplify a $306 \mathrm{bp}$ fragment specific for GAPDH. 
TABLE 2: Circulating levels, tumoral protein, and mRNA expression of IL-6.

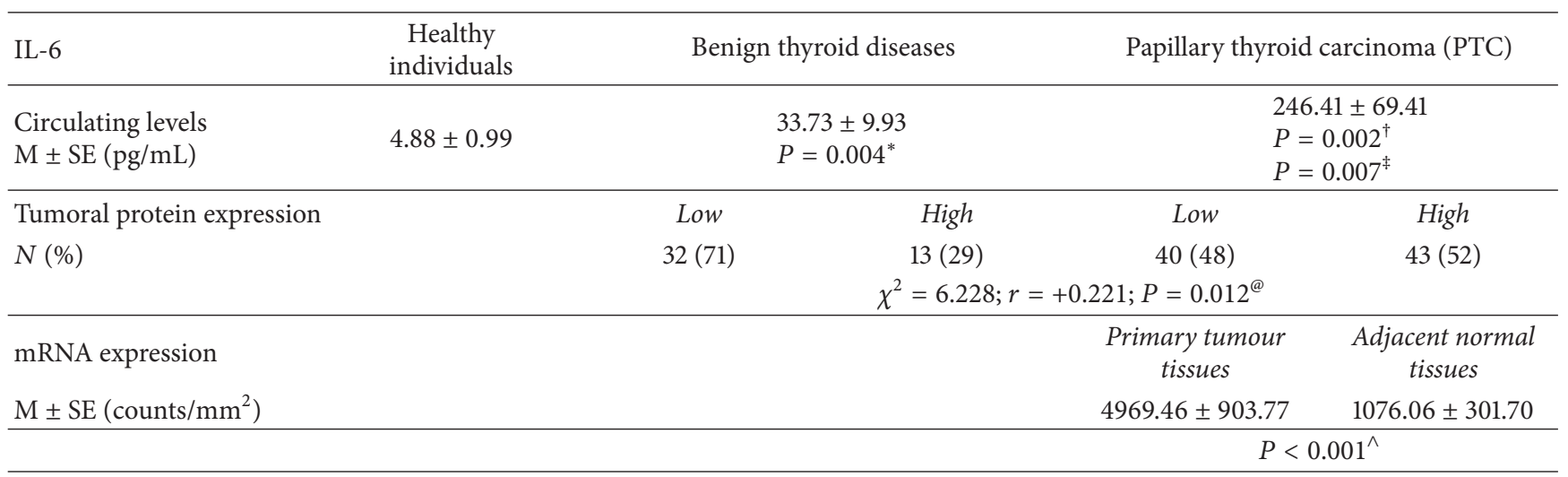

* Significance of circulating IL-6 levels between benign thyroid diseases and healthy individuals.

${ }^{\dagger}$ Significance of circulating IL-6 levels between PTC and healthy individuals.

${ }^{\ddagger}$ Significance of circulating IL-6 levels between PTC and benign thyroid diseases.

@ Significance of tumoral protein expression of IL-6 between PTC and benign thyroid diseases.

${ }^{\wedge}$ Significance of IL-6 mRNA expression between primary tumour tissues and adjacent normal tissues in PTC patients.

$1 \mu \mathrm{g}$ of total RNA was added per reaction. RT-PCR was performed in Mastercycler gradient (Eppendorf, Germany) using the following conditions: IL- 6 : $60^{\circ} \mathrm{C}$ for 30 minutes, $95^{\circ} \mathrm{C}$ for 15 minutes, followed by 36 cycles of $94^{\circ} \mathrm{C}$ for 45 seconds, $58.1^{\circ} \mathrm{C}$ for 45 seconds, and $72^{\circ} \mathrm{C}$ for 1 minute and final extension at $72^{\circ} \mathrm{C}$ for 10 minutes; and GAPDH: $60^{\circ} \mathrm{C}$ for 30 minutes, $95^{\circ} \mathrm{C}$ for 15 minutes, followed by 36 cycles of $94^{\circ} \mathrm{C}$ for 45 seconds, $60^{\circ} \mathrm{C}$ for 45 seconds, and $72^{\circ} \mathrm{C}$ for 1 minute and final extension at $72^{\circ} \mathrm{C}$ for 10 minutes. The amplified products were run on $2 \%$ agarose gels and the intensity of the products was measured as counts $/ \mathrm{mm}^{2}$ and integrated on gel documentation system (Alpha Innotech, USA) using densitometric analysis.

2.6. Statistical Analysis. The data were analyzed statistically using the Statistical Package for Social Sciences (SPSS) software version 16 (SPSS Inc., USA). Independent samples $t$-test was used to compare the means of circulating levels between two groups of subjects and also to assess the association of the analytes with the clinicopathological parameters of thyroid cancer patients. Receiver's operating characteristic (ROC) curve was constructed to determine the discriminating efficacy of the circulating IL-6 between healthy individuals and patients with thyroid diseases. Two-tailed $\chi^{2}$ test was used to compare the tumoral protein expressions in benign and carcinoma patients and also to determine association between protein expression and clinicopathological parameters of carcinoma patients. In case of less than five patients in the cells of $2 \times 2$ tables, Yate's continuity correction value along with its two-tailed significance was taken into consideration. Wilcoxon signed ranks test for two-related samples was executed to compare the mRNA expressions from the malignant and corresponding adjacent normal tissues of carcinoma patients, while the correlation of mRNA expression with clinicopathological parameters was analyzed by Mann Whitney $U$-test. Correlation between two parameters was calculated using Spearman's correlation coefficient $(r)$ method. Univariate survival analysis was evaluated using Kaplan-Meier method and log rank test was used to analyze difference in survival curves and to assess the prognostic significance of DFS and OS. Multivariate survival analysis was completed using Cox forward step-wise regression model. $P$ values $\leq 0.05$ were considered to be significant.

\section{Results}

3.1. Circulating Levels, Tumoral Protein, and mRNA Expression of IL-6. The circulating levels were expressed as Mean \pm Standard Error $(\mathrm{M} \pm \mathrm{SE})$. As compared to the healthy individuals, serum IL-6 was significantly higher in both patients with benign thyroid diseases $(P=0.004)$ and PTC $(P=0.002)$. Further, its level was also significantly higher in PTC patients as compared to the patients with benign thyroid diseases $(P=0.007)$ (Table 2).

The ROC curves also confirmed that serum IL- 6 exhibited a good discriminatory efficacy between healthy individuals and patients with benign thyroid diseases (AUC = $0.598, P=0.051$ ) (Figure 1(a)) and also between healthy individuals and PTC patients (AUC $=0.708, P<0.001$ ) (Figure 1(b)). Additionally, the circulating IL-6 levels could also significantly differentiate PTC patients from patients with benign thyroid diseases (AUC $=0.643, P=0.003$ ) (Figure 1(c)).

The expression of IL- 6 protein was localized in cytoplasm of the thyroid follicular cells. Its expression was detectable in $87 \%(39 / 45)$ of the patients with benign thyroid diseases and IRS- 4 was the median score, while in PTC patients it was detectable in $96 \%(80 / 83)$ of tumours with median IRS value as 8 . Representative staining of IL- 6 protein expression in benign thyroid and PTC lesions is shown in Figures 2(a) and 2(b), respectively. The incidence of immunoreactivity of IL-6 was significantly high in PTC patients as compared to the benign thyroid disease patients. It was noted that IL-6 expression was higher in $52 \%(43 / 83)$ of PTC patients, in comparison to only $29 \%(13 / 45)$ of benign thyroid disease 


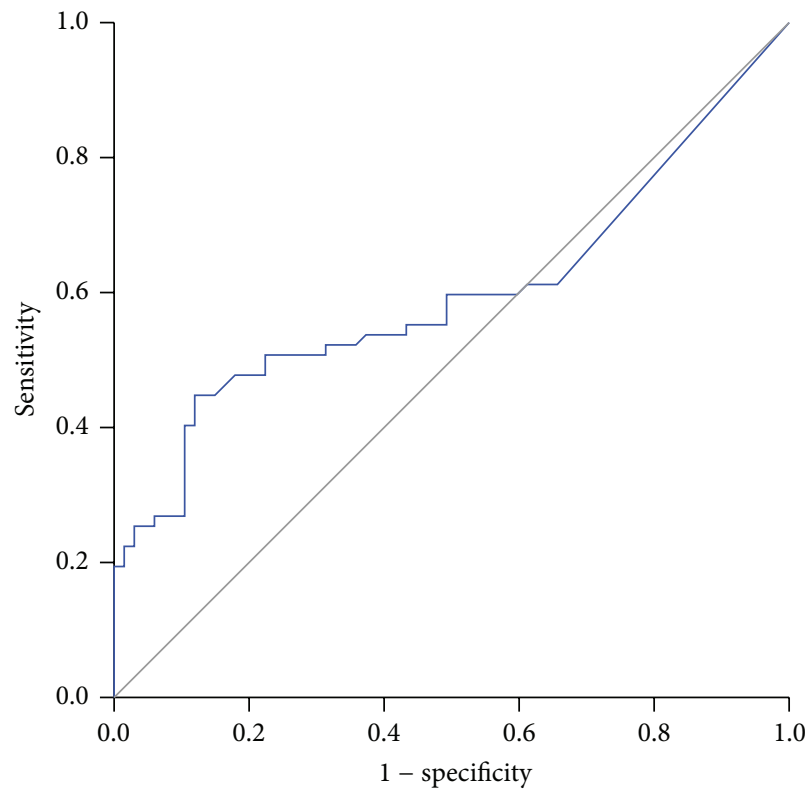

Diagonal segments are produced by ties

\begin{tabular}{ccccc}
\hline $\begin{array}{c}\text { Test result } \\
\text { variable }\end{array}$ & Area & Significance $(P)$ & \multicolumn{2}{c}{ Asymptotic 95\% confidence interval } \\
Lower bound & Upper bound \\
\hline IL-6 & 0.598 & 0.051 & 0.498 & 0.697 \\
\hline
\end{tabular}

(a)

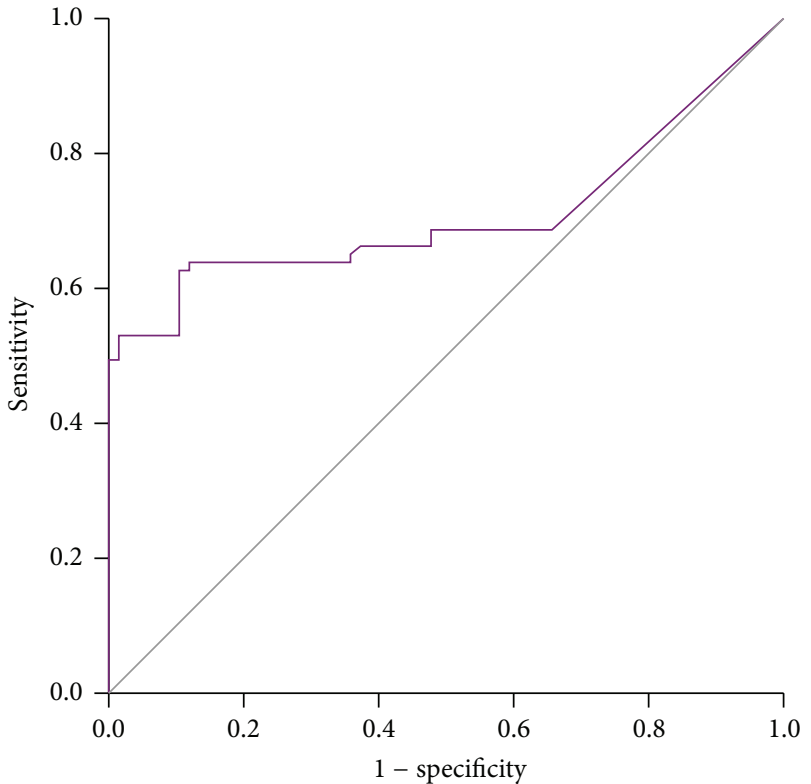

Diagonal segments are produced by ties

\begin{tabular}{ccccc}
\hline $\begin{array}{c}\text { Test result } \\
\text { variable }\end{array}$ & Area & Significance $(P)$ & $\begin{array}{c}\text { Asymptotic 95\% confidence interval } \\
\text { Lower bound }\end{array}$ & Upper bound \\
\hline IL-6 & 0.708 & $<0.001$ & 0.622 & 0.795 \\
\hline
\end{tabular}

(b)

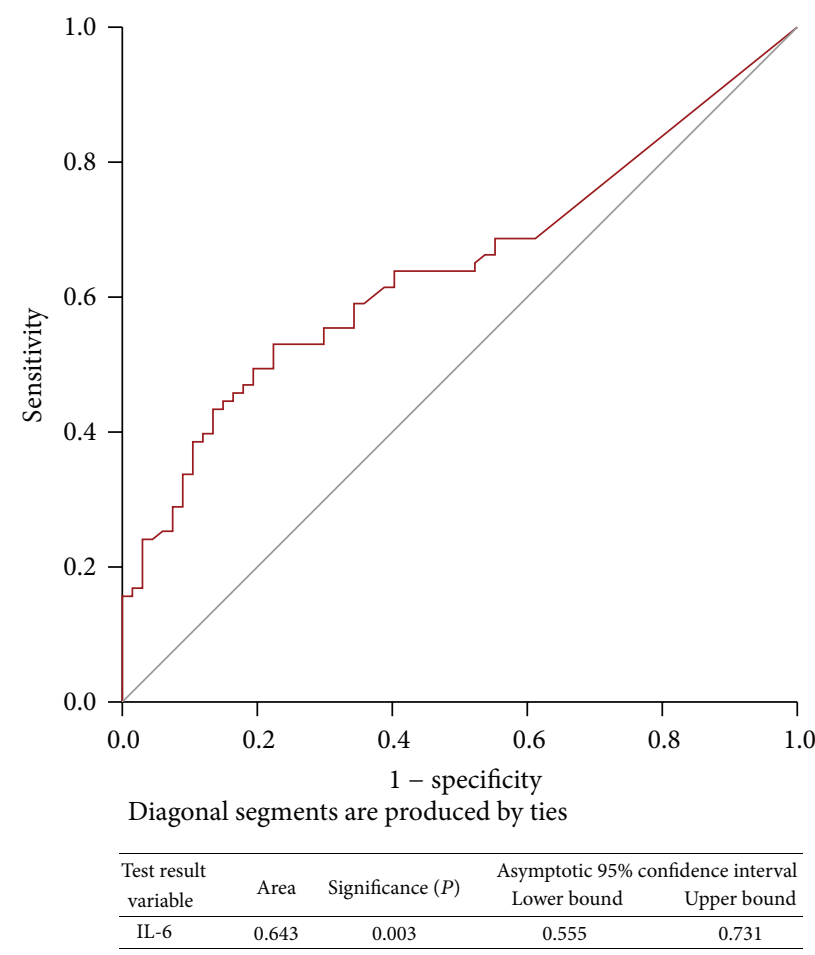

(c)

Figure 1: (a) ROC curve for IL-6 in healthy individuals versus patients with benign thyroid diseases. (b) ROC curve for IL-6 in healthy individuals versus patients with papillary thyroid carcinoma. (c) ROC curve for IL-6 in patients with benign thyroid diseases versus papillary thyroid carcinoma. 
TABLE 3: Correlation of IL-6 with clinicopathological parameters in PTC patients.

\begin{tabular}{|c|c|c|c|c|c|c|c|c|}
\hline \multirow{2}{*}{ Parameter } & \multicolumn{2}{|c|}{ Circulating levels } & \multicolumn{3}{|c|}{ Tumoral protein expression } & \multicolumn{3}{|c|}{ mRNA expression (adjacent normal tissues) } \\
\hline & $\begin{array}{c}\text { Mean } \pm \text { SE } \\
(\mathrm{pg} / \mathrm{mL})\end{array}$ & $P$ & $\begin{array}{l}\text { Low } \\
N(\%)\end{array}$ & $\begin{array}{l}\text { High } \\
N(\%)\end{array}$ & & $\begin{array}{c}\text { Mean } \pm \text { SE } \\
\left(\text { counts } / \mathrm{mm}^{2}\right)\end{array}$ & Mean rank & $P$ \\
\hline \multicolumn{9}{|l|}{ Gender } \\
\hline Female & $131.33 \pm 36.57$ & \multirow{2}{*}{0.016} & & & & & & \\
\hline Male & $485.07 \pm 193.91$ & & & & & & & \\
\hline \multicolumn{9}{|l|}{ Tumour size } \\
\hline Small $(\mathrm{T} 1+\mathrm{T} 2)$ & $94.08 \pm 37.52$ & \multirow{2}{*}{0.043} & $23(61)$ & $15(39)$ & $r=+0.227$ & $1611.52 \pm 633.60$ & 35.52 & \multirow{2}{*}{0.037} \\
\hline Large $(\mathrm{T} 3+\mathrm{T} 4)$ & $375.03 \pm 121.41$ & & $17(38)$ & $28(62)$ & $P=\mathbf{0 . 0 3 9}$ & $693.60 \pm 240.93$ & 26.91 & \\
\hline \multicolumn{9}{|l|}{ Metastasis } \\
\hline Absent & $157.17 \pm 39.51$ & \multirow[t]{2}{*}{$<0.001$} & & & & & & \\
\hline Present & $897.83 \pm 468.64$ & & & & & & & \\
\hline \multicolumn{9}{|l|}{ Capsular invasion } \\
\hline Absent & & & $31(56)$ & $24(44)$ & $r=+0.229$ & & & \\
\hline Present & & & $9(32)$ & $19(68)$ & $P=\mathbf{0 . 0 3 7}$ & & & \\
\hline \multicolumn{9}{|c|}{ Extrathyroidal extension } \\
\hline Absent & $121.81 \pm 34.33$ & \multirow{2}{*}{0.019} & $30(58)$ & $22(42)$ & $r=+0.236$ & & & \\
\hline Present & $455.04 \pm 171.98$ & & $10(32)$ & $21(68)$ & $P=\mathbf{0 . 0 2 5}$ & & & \\
\hline \multicolumn{9}{|l|}{ Residual disease } \\
\hline Absent & & & & & & $1101.40 \pm 785.08$ & 24.43 & \multirow{2}{*}{0.035} \\
\hline Present & & & & & & $1113.40 \pm 237.31$ & 33.54 & \\
\hline
\end{tabular}

$r$ : correlation coefficient.

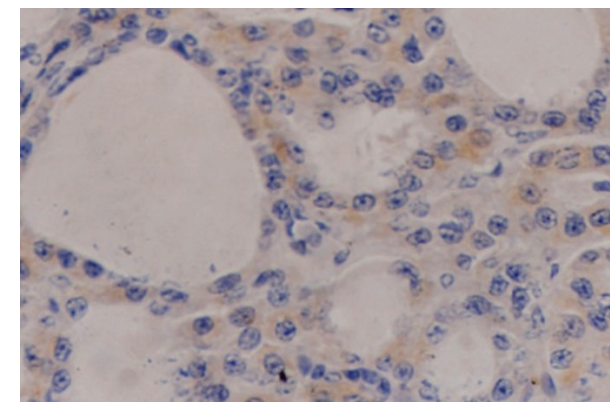

(a) IL-6 expression in benign goiter

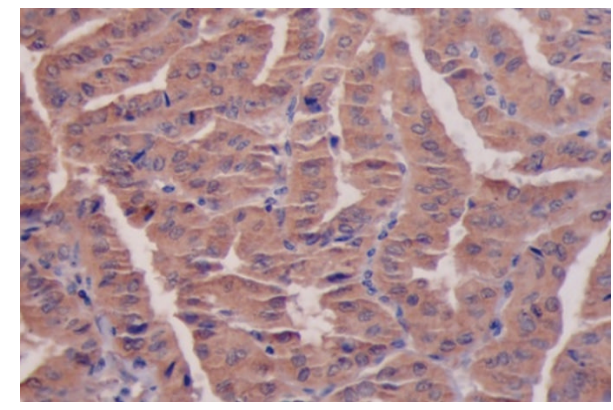

(b) IL-6 expression in PTC

FIGURE 2: Representative staining patterns of IL-6 expression in primary tumours of patients with benign thyroid diseases and PTC.

patients exhibiting higher expressions (IL-6: $\chi^{2}=6.228, r=$ $+0.221, P=0.012$ ) (Table 2, Figure 3).

In PTC patients $(N=60), \mathrm{M} \pm \mathrm{SE}$ of IL-6 mRNA expression in tumour and their adjacent normal tissues were $4969.46 \pm 903.77$ counts $/ \mathrm{mm}^{2}$ and $1076.06 \pm$ 301.70 counts $/ \mathrm{mm}^{2}$, respectively. Using nonparametric Wilcoxon signed ranks test for two-related samples, statistical significant difference was noted in IL-6 mRNA expression between tumour and corresponding adjacent normal tissues with the primary tumour tissues showing considerably higher expression of IL-6 mRNA than the adjacent normal tissues $(P<0.001)$ (Table 2). IL-6 mRNA expression in PTC patients is depicted in Figure 4(a). GAPDH was used as housekeeping gene and Figure 4(b) is the representative picture of GAPDH mRNA expression in PTC patients.
3.2. Correlation of IL-6 with Clinicopathological Parameters in PTC Patients. As shown in Table 3, the circulating IL-6 levels were found to be significantly higher in male patients $(P=0.016)$ and in PTC patients having larger tumour size $(P=0.043)$, presence of metastasis $(P<0.001)$, and extrathyroidal extension of tumours $(P=0.019)$ when compared to their respective counterparts. Moreover, the protein expression of IL-6 was found to be significantly higher in patients with larger tumour size $\left(\chi^{2}=4.270\right.$; $r=+0.227 ; P=0.039)$, in PTC patients showing capsular invasion of the tumours $\left(\chi^{2}=4.360 ; r=+0.229 ; P=0.037\right)$, and in those having extrathyroidal extension of tumours $\left(\chi^{2}=5.032 ; r=+0.236 ; P=0.025\right)$ in relation to their respective counterparts. Further, the Mann Whitney $U$-test revealed that IL-6 mRNA expression in primary tumours 


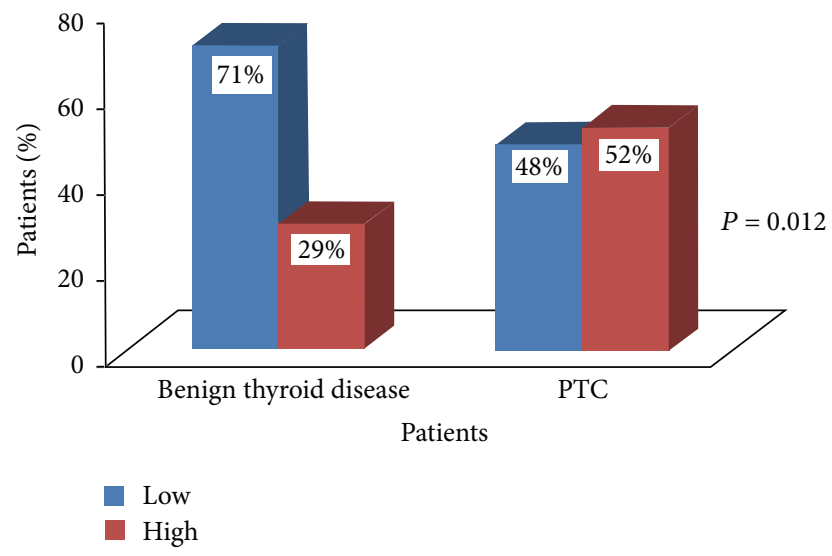

FIgURE 3: Expression of IL-6 in benign thyroid disease and PTC patients.

did not show any significant association with any of studied clinicopathological features. On the other hand, the IL-6 mRNA expression in corresponding adjacent normal tissues was significantly higher in cases with smaller tumour size $(P=0.037)$ and in patients with presence of residual disease $(P=0.035)$ as compared to those with larger tumour size and patients showing absence of residual disease, respectively.

\subsection{Association of IL-6 with Disease Free and Overall Sur-} vival in PTC Patients. Kaplan-Meier survival analysis was evaluated for DFS and OS in PTC patients. The median values of IL- 6 circulating level, median IRS score for tumoral protein expression, and the median value of IL- 6 mRNA expression were used as cut-off value to divide the PTC patients into low ( $\leq$ median) and high (>median) expression groups, respectively. The difference in survival curves was analyzed using the log rank test. Circulating IL-6 was the significant prognosticator for OS $(\log$ rank $=4.77 ; \mathrm{df}=1$; $P=0.029$ ) (Table 4(b), Figure 5) while it was not able to predict DFS in the PTC patients. Further, the Kaplan-Meier survival analysis and the log rank test revealed that neither the tumoral protein expression nor the IL-6 mRNA expressions in primary tumours or the adjacent normal tissues were able to predict DFS or OS in the PTC patients (Tables 4(a) and $4(\mathrm{~b}))$.

3.4. Intercorrelation between Circulating Levels of IL-6, Its Protein Expression, and mRNA Expression in PTC Patients. In PTC patients, the circulating levels of IL- 6 were not significantly associated with its tumoral protein expression $(r=$ $0.119, P=0.284)$ or with the mRNA expression in primary tumour $(r=-0.130, P=0.322)$ or adjacent normal tissues $(r=-0.154, P=0.241)$. Further, nonparametric Spearman's correlation revealed a significant positive correlation of IL6 protein expression with the IL- 6 mRNA expressions in the primary tumours of PTC patients $(r=0.333, P=0.009)$, while no such association was observed with the IL-6 mRNA expression in adjacent normal tissues $(r=-0.028, P=0.833)$ (Table 5).

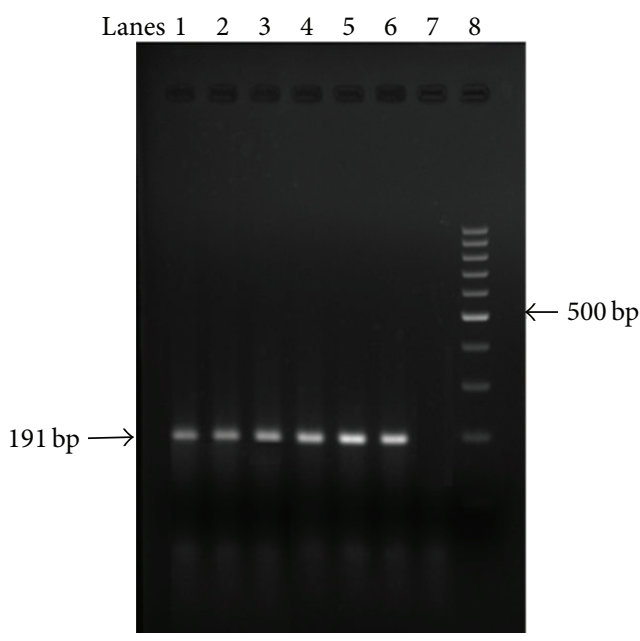

(a)

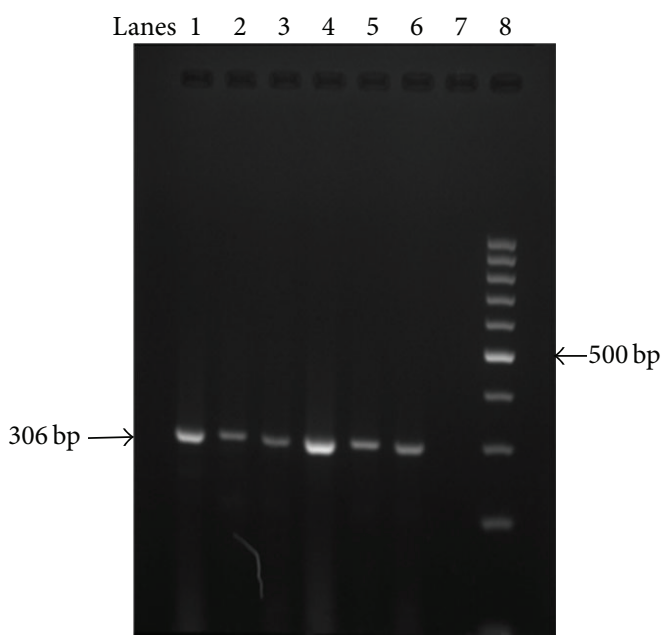

(b)

FIgURE 4: (a) Representative IL-6 mRNA expression. Lanes 1-6: presence of IL- 6 mRNA in primary tumours. Lane 7: negative control. Lane 8: 100 bp ladder. (b) Representative GAPDH mRNA expression. Lanes 1-6: presence of GAPDH in primary tumours. Lane 7: negative control. Lane 8: 100 bp ladder.

\section{Discussion}

IL-6 is one of the most widely investigated cytokines in various diseases including cancer. As concerned with its role in thyroid, the present study demonstrated significantly higher levels of circulating IL-6 in benign as well as PTC patients as compared to the healthy individuals. This finding was further supported by the ROC curves which revealed that IL- 6 could be one of the potential markers for differentiating patients with benign thyroid diseases, PTC patients from the healthy individuals. Additionally, it could also efficiently discriminate between the patients with benign thyroid diseases and PTC. Similar to present findings, Bartalena et al. reported increased serum IL-6 in multinodular goiter and they considered it as a marker of thyroid destructive inflammatory processes [28]. Recently, Provatopoulou et al. have also reported significant higher levels of serum IL-6 in 
TABLE 4: (a) Univariate survival analysis of circulating IL-6, its tumoral protein expression, and mRNA in primary tumours and adjacent normal tissues for DFS in PTC patients. (b) Univariate survival analysis of circulating IL-6, its tumoral protein expression, and mRNA in primary tumours and adjacent normal tissues for OS in PTC patients.

(a)

\begin{tabular}{|c|c|c|c|}
\hline IL-6 & $N$ & Patients relapsed $N(\%)$ & Log rank test statistics \\
\hline Circulating levels & 69 & & \multirow{3}{*}{$\log$ rank $=0.330, \mathrm{df}=1, P=0.565$} \\
\hline Low & 37 & $3(8)$ & \\
\hline High & 32 & $4(12)$ & \\
\hline Tumoral protein expression & 69 & & \\
\hline Low & 35 & $2(6)$ & \multirow{2}{*}{$\log$ rank $=1.480, \mathrm{df}=1, P=0.224$} \\
\hline High & 34 & $5(15)$ & \\
\hline mRNA expression (primary tumour tissues) & 54 & & \multirow{3}{*}{$\log$ rank $=0.119, \mathrm{df}=1, P=0.730$} \\
\hline Low & 25 & $2(8)$ & \\
\hline High & 29 & $3(10)$ & \\
\hline mRNA expression (adjacent normal tissues) & 54 & & \\
\hline Low & 32 & $3(9)$ & \multirow{2}{*}{ Log rank $=0.003, \mathrm{df}=1, P=0.958$} \\
\hline High & 22 & $2(9)$ & \\
\hline
\end{tabular}

(b)

\begin{tabular}{|c|c|c|c|}
\hline IL-6 & $N$ & Patients died N (\%) & Log rank test statistics \\
\hline Circulating levels & 76 & & \multirow{3}{*}{ Log rank $=4.772, \mathrm{df}=1, P=\mathbf{0 . 0 2 9}$} \\
\hline Low & 37 & $1(3)$ & \\
\hline High & 39 & $7(18)$ & \\
\hline Tumoral protein expression & 76 & & \\
\hline Low & 38 & $4(10)$ & \multirow{2}{*}{ Log rank $=0.001, \mathrm{df}=1, P=0.977$} \\
\hline High & 38 & $4(10)$ & \\
\hline mRNA expression (primary tumour tissues) & 60 & & \multirow{3}{*}{$\log$ rank $=1.496, \mathrm{df}=1, P=0.221$} \\
\hline Low & 30 & $5(17)$ & \\
\hline High & 30 & $2(7)$ & \\
\hline mRNA expression (adjacent normal tissues) & 60 & & \\
\hline Low & 34 & $3(9)$ & \multirow{2}{*}{$\log$ rank $=0.748, \mathrm{df}=1, P=0.387$} \\
\hline High & 26 & $4(15)$ & \\
\hline
\end{tabular}

TABLE 5: Intercorrelation between circulating levels of IL-6, its protein expression, and mRNA expression in PTC patients.

\begin{tabular}{lcc}
\hline $\begin{array}{l}\text { IL-6 mRNA } \\
\text { expression }\end{array}$ & Circulating IL-6 levels & $\begin{array}{c}\text { IL-6 protein } \\
\text { expression }\end{array}$ \\
\hline Primary & $r=-0.130$ & $r=0.333$ \\
tumours & $P=0.322$ & $P=\mathbf{0 . 0 0 9}$ \\
Adjacent & $r=-0.154$ & $r=-0.028$ \\
normal tissues & $P=0.241$ & $P=0.833$ \\
& $r=0.119, P=0.284$ \\
\hline
\end{tabular}

$r$ : correlation coefficient.

patients with benign thyroid conditions and thyroid cancer, compared to healthy controls [29]. Also serum IL-6 levels were also found to be elevated in patients with chronic liver disease including cirrhosis and HCC [30]. Giannitrapani et al. have reported that IL-6 levels were significantly higher in HCC patients than that in patients with liver cirrhosis [31]. Similar to this and the current results, Uchiyama et al. have also shown increased levels of serum IL-6 in colorectal cancer as compared to patients with adenoma [32] while Szkaradkiewicz et al. demonstrated that IL-6 levels were elevated in both patients with inflammatory bowel disease and colorectal cancer [33]. Multiple studies have consistently reported that, as compared to the healthy controls, the circulating levels of IL-6 were significantly higher in patients with different malignancies like colorectal cancer [33-36], breast cancer [37-40], pancreatic cancer [41], gastroesophageal cancer [42], gastric cancer [43], and non-small-cell lung carcinoma [44]. Moreover, Sun et al. have also observed that IL- 6 was able to promote the proliferation of nasopharyngeal carcinoma [45].

Further, in present study, when serum IL- 6 was correlated with various clinicopathological parameters of PTC patients, it was noted that levels of IL-6 showed a significant positive correlation with larger tumour size, presence of distant metastasis at the time of diagnosis, and extrathyroidal extension of tumours. Moreover, male patients had predominantly higher levels of IL- 6 than the female patients. In their studies, Salgado et al., Goswami et al., Dethlefsen et al., Tripsianis et al., and Sanguinetti et al. have suggested that IL-6 assumes a role in the upregulation of malignant characteristics in breast cancer cells and that high IL-6 serum levels are associated with poor outcome in breast cancer patients [40, 46-49]. Data 


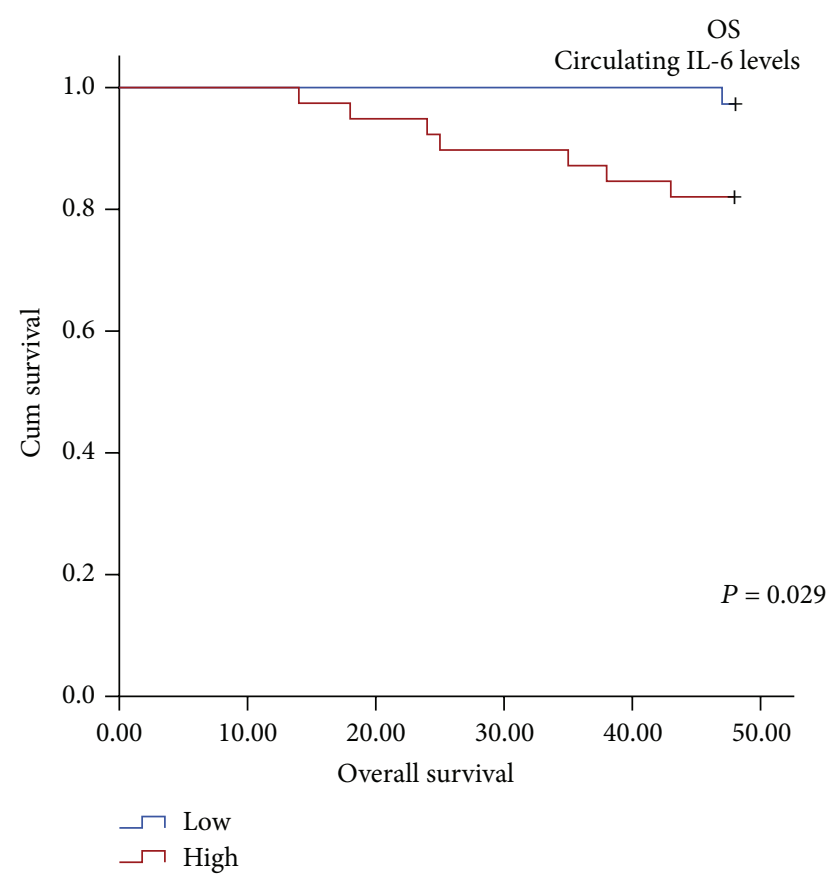

FIGURE 5: Significantly reduced OS observed in PTC patients with high levels of serum IL-6 as compared to its counterpart.

from epidemiological studies is also accruing in support of a contributory role of elevated circulating IL-6 in patients with advanced tumour stages and aggressive behaviour of various cancers, such as non-small-cell lung cancer, colorectal cancer, breast cancer, and renal cell carcinoma [11, 35, 39, 50-54]. IL- 6 has been implicated as an autocrine promoter of cancer growth for various human cancers such as biliary tract epithelial cancers, multiple myeloma, and prostate cancer $[55,56]$. Knüpfer and Preiss revealed that higher IL-6 levels were significantly associated with tumour size, metastasis, stage, and decreased survival in colorectal cancer patients [34] and Ahmed et al. have demonstrated its association with tumour size in breast cancer patients [37]. It can be suggested through these observations that circulating IL-6 may be partly derived from spillover of tumour produced IL-6 which hereby explains the association of high IL-6 levels with larger tumour size and presence of extrathyroidal extension of tumours.

The present study also demonstrates that higher circulating level of IL-6 was significantly associated with poor OS in PTC patients. Nakashima et al. have reported IL-6 to be independently associated with survival in prostate cancer patients [57]. Its role as an independent negative prognostic factor in patients with lymphoma has been confirmed by El Far et al. [58], and Lai et al. reported that IL-6 may be a prognostic marker in patients with Hodgkin disease or B-chronic lymphocytic leukemia [59]. Schultz et al. have demonstrated circulating IL-6 as an independent prognostic biomarker of OS in patients with locally advanced or metastatic pancreatic cancer [60]. IL-6 plays a key role as prognostic factor even in gastric cancer invasion and metastasis and its elevated level in circulation predicts shorter survival $[61,62]$. Researchers have observed that serum IL-6 concentration was associated with the progression, histological grade, and bowel wall invasion $[63,64]$ as well as tumour size and shorter survival periods of colorectal cancer [65]. Recently, Lu et al. have suggested the use of IL- 6 concentration in the serum as an indicator of the possibility of colorectal cancer recurrence [66].

Further, the current study observed significant higher cytoplasmic expression of IL-6 protein in the primary tumours of PTC patients than in the patients with benign thyroid disease patients. The overexpression of IL-6 in PTC patients was significantly and linearly correlated with larger tumour size, presence of capsular invasion, and extrathyroidal extension of tumours. Consistent with the present finding, cytoplasmic staining pattern for IL-6 expression was also observed in ovarian cancer [67], renal cell carcinoma [68], colorectal cancer [50], and gastric cancer [61]. Expressions of IL- 6 have also been observed to be higher in the primary tumour tissues than the adjacent normal tissues in prostate cancer [69], breast cancer [70], and esophageal squamous cell carcinoma $[71,72]$ as well as gastric cancer $[62$, 73]. Moreover, Depner et al. observed that IL-6 expression was strongly upregulated upon progression from benign tumours to highly malignant, metastasizing human skin squamous cell carcinoma [74]. Increased expression of IL-6 immunoreactivity in oral squamous cell carcinoma was more frequently observed in patients with advanced stage, cervical lymph node metastasis, or distant metastasis [75]. Moreover, Il-6 expression was significantly increased in advanced stage as compared to early stage of gastric cancer [73] and colorectal carcinoma [50]. However, Paule et al. found no significant difference in tumour size or grade between renal cell carcinomas with or without expression of IL-6 [68]. Moreover in the present study, IL-6 protein expression did not have a definite role in prognosis of the PTC patients. Similar to current observation, IL-6 expression in the primary tumours of patients with ovarian cancer and gall bladder cancer failed to show significant correlations with prognosis $[67,76]$. Contradictory to this, IL-6 expression has been found to be significantly associated with poor prognosis in OSCC patients [75, 77], esophageal squamous cell carcinoma [72], colorectal cancer [50], and ovarian cancer [23]. In a study on colorectal cancer by Chung et al., the tissue expression of IL-6 did not correlate with the serum IL-6 levels, which is comparable to the present finding [50].

In addition to this, in the present study, the IL- 6 mRNA expression was higher in the primary tumour tissues of PTC patients as compared to the corresponding adjacent normal tissues. Similar results have been reported in esophageal squamous cell carcinoma [71] and colorectal cancer [32, 66]. Moreover, Sanguinetti et al. have shown that mammospheres from node invasive breast cancer tissues express IL-6 mRNA at higher levels than the mammospheres from matched nonneoplastic mammary glands [49]. In the present study, the mRNA levels in the primary tumours were not associated with any of the clinicopathological parameters or with prognosis in PTC patients but its levels in the corresponding adjacent normal tissues were significantly higher in the PTC patients having smaller tumour size and 
presence of residual disease after surgery. This may be because although apparently looking normal, biologically there might be some malignant changes in the adjacent normal tissues of such patients and the concept of field cancerization may follow here. Moreover, a significant positive correlation was observed between the IL- 6 protein and mRNA expression in the primary tumours of PTC patients. Data reported by Basolo et al. and Ruggeri et al. support that IL-6 tissue expression is related to aggressiveness in PTC [78, 79]. Further, Basolo et al. had shown that downregulation of IL-6 expression may represent a marker of undifferentiated thyroid carcinoma [78]. Moreover, it has also been revealed that certain polymorphisms in the genes encoding IL- 6 have been associated with the risk of PTC [80]. Currently, humanized anti- IL-6 receptor monoclonal antibody tocilizumab has been adopted as a first-line biologic therapy for treatment of moderate-to-severe rheumatoid arthritis and for Castleman's disease.

\section{Conclusion}

From the present study, it can be evident that IL-6 has a significant role in thyroid cancer progression and targeting IL-6 signalling can be helpful in clinical management of thyroid carcinoma patients with more aggressive tumour characteristics.

\section{Competing Interests}

The authors declare that they have no competing interests.

\section{Acknowledgments}

This work was financially supported by Gujarat Cancer Society (GCS), and it was approved by the GCRI/GCS ethics committee.

\section{References}

[1] T. Nagasaki, M. Hara, H. Nakanishi, H. Takahashi, M. Sato, and H. Takeyama, "Interleukin- 6 released by colon cancerassociated fibroblasts is critical for tumour angiogenesis: antiinterleukin-6 receptor antibody suppressed angiogenesis and inhibited tumour-stroma interaction," British Journal of Cancer, vol. 110, no. 2, pp. 469-478, 2014.

[2] T. Kishimoto, "Interleukin-6: from basic science to medicine40 Years in immunology," Annual Review of Immunology, vol. 23, pp. 1-21, 2005.

[3] T. Kishimoto, "IL-6: from its discovery to clinical applications," International Immunology, vol. 22, no. 5, pp. 347-352, 2010.

[4] K. Tawara, J. T. Oxford, and C. L. Jorcyk, "Clinical significance of interleukin (IL)- 6 in cancer metastasis to bone: potential of anti-IL-6 therapies," Cancer Management and Research, vol. 3, no. 1, pp. 177-189, 2011.

[5] S. Grivennikov, E. Karin, J. Terzic et al., "IL-6 and Stat3 are required for survival of intestinal epithelial cells and development of colitis-associated cancer," Cancer Cell, vol. 15, no. 2, pp. 103-113, 2009.
[6] T. Ara and Y. A. DeClerck, "Interleukin-6 in bone metastasis and cancer progression," European Journal of Cancer, vol. 46, no. 7, pp. 1223-1231, 2010.

[7] F. R. Santer, K. Malinowska, Z. Culig, and I. T. Cavarretta, "Interleukin-6 trans-signalling differentially regulates proliferation, migration, adhesion and maspin expression in human prostate cancer cells," Endocrine-Related Cancer, vol. 17, no. 1, pp. 241-253, 2010.

[8] H. Yi, H.-J. Cho, S.-M. Cho et al., "Blockade of interleukin-6 receptor suppresses the proliferation of $\mathrm{H} 460$ lung cancer stem cells," International Journal of Oncology, vol. 41, no. 1, pp. 310316, 2012.

[9] G. Xie, Q. Yao, Y. Liu et al., "IL-6-induced epithelialmesenchymal transition promotes the generation of breast cancer stem-like cells analogous to mammosphere cultures," International Journal of Oncology, vol. 40, no. 4, pp. 1171-1179, 2012.

[10] K.-Y. Yeh, Y.-Y. Li, L.-L. Hsieh et al., "Analysis of the effect of serum interleukin-6 (IL-6) and soluble IL-6 receptor levels on survival of patients with colorectal cancer," Japanese Journal of Clinical Oncology, vol. 40, no. 6, pp. 580-587, 2010.

[11] S. Mitsunaga, M. Ikeda, S. Shimizu et al., "Serum levels of IL6 and IL-1 $\beta$ can predict the efficacy of gemcitabine in patients with advanced pancreatic cancer," British Journal of Cancer, vol. 108, no. 10, pp. 2063-2069, 2013.

[12] J. Shimazaki, Y. Goto, K. Nishida et al., "In patients with colorectal cancer, preoperative serum interleukin-6 level and granulocyte/lymphocyte ratio are clinically relevant biomarkers of long-term cancer progression," Oncology, vol. 84, no. 6, pp. 356-361, 2013.

[13] I. T. Cavarretta, H. Neuwirt, G. Untergasser et al., "The antiapoptotic effect of IL-6 autocrine loop in a cellular model of advanced prostate cancer is mediated by Mcl-1," Oncogene, vol. 26, no. 20, pp. 2822-2832, 2007.

[14] U. H. Weidle, S. Klostermann, D. Eggle, and A. Krüger, "Interleukin 6/interleukin 6 receptor interaction and its role as a therapeutic target for treatment of cachexia and cancer," Cancer Genomics and Proteomics, vol. 7, no. 6, pp. 287-302, 2010.

[15] M. T. Lin, B. R. Lin, C. C. Chang et al., "IL-6 induces AGS gastric cancer cell invasion via activation of the c-Src/RhoA/ROCK signaling pathway," International Journal of Cancer, vol. 120, pp. 2600-2608, 2007.

[16] Z. T. Schafer and J. S. Brugge, "IL-6 involvement in epithelial cancers," The Journal of Clinical Investigation, vol. 117, no. 12, pp. 3660-3663, 2007.

[17] V. W. S. Wong, J. Yu, A. S. L. Cheng et al., "High serum interleukin-6 level predicts future hepatocellular carcinoma development in patients with chronic hepatitis B," International Journal of Cancer, vol. 124, no. 12, pp. 2766-2770, 2009.

[18] C.-C. Chen, W.-C. Chen, C.-H. Lu et al., "Significance of interleukin- 6 signaling in the resistance of pharyngeal cancer to irradiation and the epidermal growth factor receptor inhibitor," International Journal of Radiation Oncology, Biology, Physics, vol. 76, no. 4, pp. 1214-1224, 2010.

[19] Z. Han, J. Feng, Z. Hong et al., "Silencing of the STAT3 signaling pathway reverses the inherent and induced chemoresistance of human ovarian cancer cells," Biochemical and Biophysical Research Communications, vol. 435, no. 2, pp. 188-194, 2013.

[20] H. Q. Yan, X. B. Huang, S. Z. Ke et al., "Interleukin 6 augments lung cancer chemotherapeutic resistance via ataxiatelangiectasia mutated/NF-kappaB pathway activation," Cancer Science, vol. 105, no. 9, pp. 1220-1227, 2014. 
[21] M. Mihara, N. Nishimoto, and Y. Ohsugi, "The therapy of autoimmune diseases by anti-interleukin-6 receptor antibody," Expert Opinion on Biological Therapy, vol. 5, no. 5, pp. 683-690, 2005.

[22] M. S. Anglesio, J. George, H. Kulbe et al., "IL6-STAT3-HIF signaling and therapeutic response to the angiogenesis inhibitor sunitinib in ovarian clear cell cancer," Clinical Cancer Research, vol. 17, no. 8, pp. 2538-2548, 2011.

[23] J. Coward, H. Kulbe, P. Chakravarty et al., "Interleukin-6 as a therapeutic target in human ovarian cancer," Clinical Cancer Research, vol. 17, no. 18, pp. 6083-6096, 2011.

[24] V. Erol, Ö. Makay, G. Içöz et al., "The importance of staging systems for the determination of prognosis of well-differentiated thyroid cancer," Turkish Journal of Surgery, vol. 29, no. 1, pp. 710, 2013.

[25] T. P. Kobawala, T. I. Trivedi, K. K. Gajjar, D. H. Patel, G. H. Patel, and N. R. Ghosh, "Significance of TNF- $\alpha$ and the adhesion molecules: L-selectin and VCAM-1 in papillary thyroid carcinoma," Journal of Thyroid Research, vol. 2016, Article ID 8143695, 17 pages, 2016.

[26] W. Remmele and H. E. Stegner, "Recommendation for uniform definition of an immunoreactive score (IRS) for immunohistochemical estrogen receptor detection (ER-ICA) in breast cancer tissue," Pathologe, vol. 8, no. 3, pp. 138-140, 1987.

[27] P. Chomczynski and N. Sacchi, "Single-step method of RNA isolation by acid guanidinium thiocyanate-phenol-chloroform extraction," Analytical Biochemistry, vol. 162, no. 1, pp. 156-159, 1987.

[28] L. Bartalena, S. Brogioni, L. Grasso et al., "Interleukin-6: a marker of thyroid-destructive processes?" The Journal of Clinical Endocrinology \& Metabolism, vol. 79, no. 5, pp. 14241427, 1994.

[29] X. Provatopoulou, D. Georgiadou, T. N. Sergentanis et al., "Interleukins as markers of inflammation in malignant and benign thyroid disease," Inflammation Research, vol. 63, no. 8, pp. 667-674, 2014.

[30] M. Trikha, R. Corringham, B. Klein, and J.-F. Rossi, “Targeted anti-interleukin-6 monoclonal antibody therapy for cancer: a review of the rationale and clinical evidence," Clinical Cancer Research, vol. 9, no. 13, pp. 4653-4665, 2003.

[31] L. Giannitrapani, M. Soresi, A. Giacalone et al., "IL-6-174G/C polymorphism and IL-6 serum levels in patients with liver cirrhosis and hepatocellular carcinoma," OMICS: A Journal of Integrative Biology, vol. 15, no. 3, pp. 183-186, 2011.

[32] T. Uchiyama, H. Takahashi, H. Endo et al., "IL-6 plays crucial roles in sporadic colorectal cancer through the cytokine networks including CXCL7," Journal of Cancer Therapy, vol. 3, no. 6, pp. 874-879, 2012.

[33] A. Szkaradkiewicz, R. Marciniak, I. Chudzicka-Strugała et al., "Proinflammatory cytokines and IL-10 in inflammatory bowel disease and colorectal cancer patients," Archivum Immunologiae et Therapiae Experimentalis, vol. 57, no. 4, pp. 291-294, 2009.

[34] H. Knüpfer and R. Preiss, "Serum interleukin-6 levels in colorectal cancer patients-a summary of published results," International Journal of Colorectal Disease, vol. 25, no. 2, pp. 135140, 2010.

[35] J. Wang, K. Xu, J. Wu et al., "The changes of Th17 cells and the related cytokines in the progression of human colorectal cancers," BMC Cancer, vol. 12, article 418, 2012.

[36] S. Neagu, L. Lerescu, R. Costea et al., "Perioperative immunologic changes in colorectal cancer patients," Chirurgia (Bucharest, Romania: 1990), vol. 107, no. 1, pp. 59-65, 2012.
[37] O. I. Ahmed, A. M. Adel, D. R. Diab, and N. S. Gobran, "Prognostic value of serum level of interleukin- 6 and interleukin-8 in metastatic breast cancer patients," The Egyptian journal of immunology/Egyptian Association of Immunologists, vol. 13, no. 2, pp. 61-68, 2006.

[38] D. Nariţa, E. Seclaman, S. Ursoniu, R. Ilina, N. Cireap, and A. Anghel, "Expression of CCL18 and interleukin-6 in the plasma of breast cancer patients as compared with benign tumor patients and healthy controls," Romanian Journal of Morphology and Embryology, vol. 52, no. 4, pp. 1261-1267, 2011.

[39] N. Gupta, B. Goswami, and P. Mittal, "Effect of standard anthracycline based neoadjuvant chemotherapy on circulating levels of serum IL-6 in patients of locally advanced carcinoma breast-a prospective study," International Journal of Surgery, vol. 10, no. 10, pp. 638-640, 2012.

[40] G. Tripsianis, E. Papadopoulou, K. Anagnostopoulos et al., "Coexpression of IL- 6 and TNF- $\alpha$ : prognostic significance on breast cancer outcome," Neoplasma, vol. 61, no. 2, pp. 205-212, 2014.

[41] W. Błogowski, A. Deskur, M. Budkowska et al., "Selected cytokines in patients with pancreatic cancer: a preliminary report," PLoS ONE, vol. 9, no. 5, Article ID e97613, 2014.

[42] M. Krzystek-Korpacka, M. Matusiewicz, D. Diakowska et al., "Impact of weight loss on circulating IL-1, IL-6, IL-8, TNF$\alpha$, VEGF-A, VEGF-C and midkine in gastroesophageal cancer patients," Clinical Biochemistry, vol. 40, no. 18, pp. 1353-1360, 2007.

[43] H. K. Kim, K. S. Song, Y. S. Park et al., "Elevated levels of circulating platelet microparticles, VEGF, IL-6 and RANTES in patients with gastric cancer: possible role of a metastasis predictor," European Journal of Cancer, vol. 39, no. 2, pp. 184191, 2003.

[44] D. J. McKeown, D. J. F. Brown, A. Kelly, A. M. Wallace, and D. C. McMillan, "The relationship between circulating concentrations of C-reactive protein, inflammatory cytokines and cytokine receptors in patients with non-small-cell lung cancer," British Journal of Cancer, vol. 91, no. 12, pp. 1993-1995, 2004.

[45] W. Sun, D.-B. Liu, W.-W. Li et al., "Interleukin-6 promotes the migration and invasion of nasopharyngeal carcinoma cell lines and upregulates the expression of MMP-2 and MMP-9," International Journal of Oncology, vol. 44, no. 5, pp. 1551-1560, 2014.

[46] R. Salgado, S. Junius, I. Benoy et al., "Circulating interleukin6 predicts survival in patients with metastatic breast cancer," International Journal of Cancer, vol. 103, no. 5, pp. 642-646, 2003.

[47] B. Goswami, P. Mittal, and N. Gupta, "Correlation of levels of IL-6 with tumor burden and receptor status in patients of locally advanced carcinoma breast," Indian Journal of Clinical Biochemistry, vol. 28, no. 1, pp. 90-94, 2013.

[48] C. Dethlefsen, G. Højfeldt, and P. Hojman, "The role of intratumoral and systemic IL-6 in breast cancer," Breast Cancer Research and Treatment, vol. 138, no. 3, pp. 657-664, 2013.

[49] A. Sanguinetti, D. Santini, M. Bonafè, M. Taffurelli, and N. Avenia, "Interleukin-6 and pro inflammatory status in the breast tumor microenvironment," World Journal of Surgical Oncology, vol. 13, article 129, 2015.

[50] Y.-C. Chung, Y.-L. Chaen, and C.-P. Hsu, "Clinical significance of tissue expression of interleukin-6 in colorectal carcinoma," Anticancer Research, vol. 26, no. 5, pp. 3905-3911, 2006. 
[51] C. M. Jacobson, B. Rosenfeld, H. Pessin, and W. Breitbart, "Depression and IL-6 blood plasma concentrations in advanced cancer patients," Psychosomatics, vol. 49, no. 1, pp. 64-66, 2008.

[52] P. Ravishankaran and R. Karunanithi, "Clinical significance of preoperative serum interleukin-6 and C-reactive protein level in breast cancer patients," World Journal of Surgical Oncology, vol. 9, article 18, 2011.

[53] Y. Guo, F. Xu, T. Lu, Z. Duan, and Z. Zhang, "Interleukin6 signaling pathway in targeted therapy for cancer," Cancer Treatment Reviews, vol. 38, no. 7, pp. 904-910, 2012.

[54] G. J. K. Guthrie, C. S. D. Roxburgh, C. H. Richards, P. G. Horgan, and D. C. McMillan, "Circulating IL-6 concentrations link tumour necrosis and systemic and local inflammatory responses in patients undergoing resection for colorectal cancer," British Journal of Cancer, vol. 109, no. 1, pp. 131-137, 2013.

[55] S. Kobayashi, N. W. Werneburg, S. F. Bronk, S. H. Kaufmann, and G. J. Gores, "Interleukin-6 contributes to Mcl-1 upregulation and TRAIL resistance via an Akt-signaling pathway in cholangiocarcinoma cells," Gastroenterology, vol. 128, no. 7, pp. 2054-2065, 2005.

[56] F. Meng, Y. Yamagiwa, S. Taffetani, J. Han, and T. Patel, "IL-6 activates serum and glucocorticoid kinase via p38 $\alpha$ mitogenactivated protein kinase pathway," The American Journal of Physiology-Cell Physiology, vol. 289, no. 4, pp. C971-C981, 2005.

[57] J. Nakashima, M. Tachibana, Y. Horiguchi et al., "Serum interleukin 6 as a prognostic factor in patients with prostate cancer," Clinical Cancer Research, vol. 6, no. 7, pp. 2702-2706, 2000.

[58] M. El Far, M. Fouda, R. Yahya, and H. El Baz, "Serum IL10 and IL-6 levels at diagnosis as independent predictors of outcome in non-Hodgkin's lymphoma," Journal of Physiology and Biochemistry, vol. 60, no. 4, pp. 253-258, 2004.

[59] R. Lai, S. O'Brien, T. Maushouri et al., "Prognostic value of plasma interleukin-6 levels in patients with chronic lymphocytic leukemia," Cancer, vol. 95, no. 5, pp. 1071-1075, 2002.

[60] N. A. Schultz, I. J. Christensen, J. Werner et al., "Diagnostic and prognostic impact of circulating YKL-40, IL-6, and CA 19.9 in patients with pancreatic cancer," PLoS ONE, vol. 8, no. 6, Article ID e67059, 2013.

[61] T. Ashizawa, R. Okada, Y. Suzuki et al., "Clinical significance of interleukin-6 (IL-6) in the spread of gastric cancer: role of IL-6 as a prognostic factor," Gastric Cancer, vol. 8, no. 2, pp. 124-131, 2005.

[62] Y. Yin, X. Si, Y. Gao, L. Gao, and J. Wang, "The nuclear factor$\kappa \mathrm{B}$ correlates with increased expression of interleukin- 6 and promotes progression of gastric carcinoma," Oncology Reports, vol. 29, no. 1, pp. 34-38, 2013.

[63] J. Kaminska, M. P. Nowacki, M. Kowalska et al., "Clinical significance of serum cytokine measurements in untreated colorectal cancer patients: soluble tumor necrosis factor receptor type Ian independent prognostic factor," Tumor Biology, vol. 26, no. 4, pp. 186-194, 2005.

[64] F. Esfandi, S. M. Ghobadloo, and G. Basati, "Interleukin-6 level in patients with colorectal cancer," Cancer Letters, vol. 244, no. 1, pp. 76-78, 2006.

[65] N. I. Nikiteas, N. Tzanakis, M. Gazouli et al., "Serum IL-6, TNFalpha and CRP levels in Greek colorectal cancer patients: prognostic implications," World Journal of Gastroenterology, vol. 11, pp. 1639-1643, 2005.

[66] C.-C. Lu, H.-C. Kuo, F.-S. Wang, M.-H. Jou, K.-C. Lee, and J.-H. Chuang, "Upregulation of TLRs and IL-6 as a marker in human colorectal cancer," International Journal of Molecular Sciences, vol. 16, no. 1, pp. 159-177, 2015.

[67] A. Isobe, K. Sawada, Y. Kinose et al., "Interleukin 6 receptor is an independent prognostic factor and a potential therapeutic target of ovarian cancer," PLoS ONE, vol. 10, no. 2, Article ID e0118080, 2015.

[68] B. Paule, J. Belot, C. Rudant, C. Coulombel, and C. C. Abbou, "The importance of IL-6 protein expression in primary human renal cell carcinoma: an immunohistochemical study," Journal of Clinical Pathology, vol. 53, no. 5, pp. 388-390, 2000.

[69] P. F. Engelhardt, S. Seklehner, H. Brustmann, L. Lusuardi, and C. R. Riedl, "Immunohistochemical expression of interleukin-2 receptor and interleukin- 6 in patients with prostate cancer and benign prostatic hyperplasia: association with asymptomatic inflammatory prostatitis NIH category IV,' Scandinavian Journal of Urology, vol. 49, no. 2, pp. 120-126, 2014.

[70] V. Labovsky, L. M. Martinez, K. M. Davies et al., "Association between ligands and receptors related to the progression of early breast cancer in tumor epithelial and stromal cells," Clinical Breast Cancer, vol. 15, no. 1, pp. e13-e21, 2015.

[71] D. Chen, L. Jin, L. Zhu, X. Mou, S. Wang, and C. Mao, "Expressions and correlations of let-7a and IL-6 in esophageal squamous cell carcinoma," Chinese Journal of Cellular and Molecular Immunology, vol. 29, no. 11, pp. 1181-1184, 2013.

[72] M.-F. Chen, P.-T. Chen, M. S. Lu, P. Y. Lin, W.-C. Chen, and K.-D. Lee, "IL-6 expression predicts treatment response and outcome in squamous cell carcinoma of the esophagus," Molecular Cancer, vol. 12, article 26, 2013.

[73] Z. Wang, X. Si, A. Xu et al., "Activation of STAT3 in human gastric cancer cells via interleukin (IL)-6-type cytokine signaling correlates with clinical implications," PLoS ONE, vol. 8, no. 10, Article ID e75788, 2013.

[74] S. Depner, W. Lederle, C. Gutschalk, N. Linde, A. Zajonz, and M. M. Mueller, "Cell type specific interleukin-6 induced responses in tumor keratinocytes and stromal fibroblasts are essential for invasive growth," International Journal of Cancer, vol. 135, no. 3, pp. 551-562, 2014.

[75] T. Jinno, S. Kawano, Y. Maruse et al., "Increased expression of interleukin- 6 predicts poor response to chemoradiotherapy and unfavorable prognosis in oral squamous cell carcinoma," Oncology Reports, vol. 33, no. 5, pp. 2161-2168, 2015.

[76] A. Chaturmohta, R. Dixit, G. Narayan et al., "Do expression profiles of cytokines VEGF, TNF- $\alpha$, IL- $1 \beta$, IL-6 and IL-8 correlate with gallbladder cancer?" Journal of Cancer Science and Clinical Oncology 2, vol. 2, no. 202, 2015.

[77] C. J. Chen, W. W. Sung, Y. M. Lin et al., "Gender difference in the prognostic role of interleukin 6 in oral squamous cell carcinoma," PLoS ONE, vol. 7, no. 11, Article ID e50104, 2012.

[78] F. Basolo, L. Fiore, L. Pollina, G. Fontanini, P. G. Conaldi, and A. Toniolo, "Reduced expression of interleukin 6 in undifferentiated thyroid carcinoma: in vitro and in vivo studies," Clinical Cancer Research, vol. 4, no. 2, pp. 381-387, 1998.

[79] R. M. Ruggeri, D. Villari, A. Simone et al., "Co-expression of interleukin-6 (IL-6) and interleukin-6 receptor (IL-6R) in thyroid nodules is associated with co-expression of CD30 ligand/CD30 receptor," Journal of Endocrinological Investigation, vol. 25, no. 11, pp. 959-966, 2002.

[80] A. G. Ozgen, M. Karadeniz, M. Erdogan, A. Berdeli, F. Saygili, and C. Yilmaz, "The (-174) G/C polymorphism in the interleukin- 6 gene is associated with risk of papillary thyroid carcinoma in Turkish patients," Journal of Endocrinological Investigation, vol. 32, no. 6, pp. 491-494, 2009. 


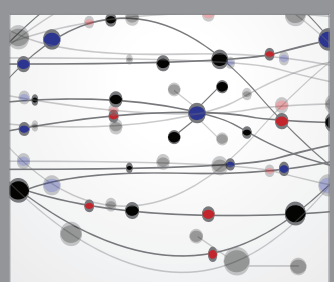

The Scientific World Journal
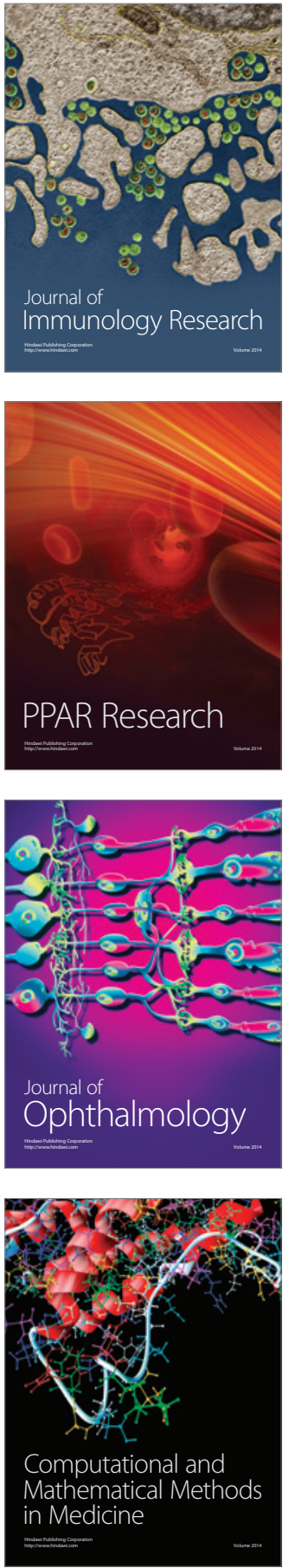

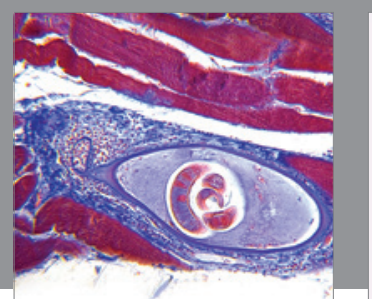

Gastroenterology Research and Practice

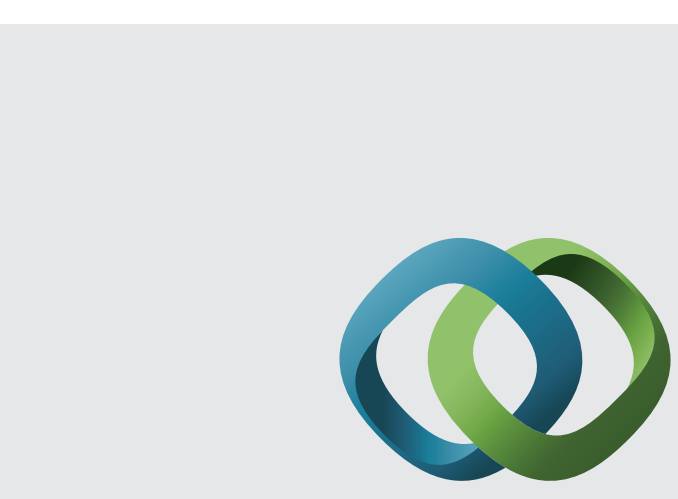

\section{Hindawi}

Submit your manuscripts at

http://www.hindawi.com
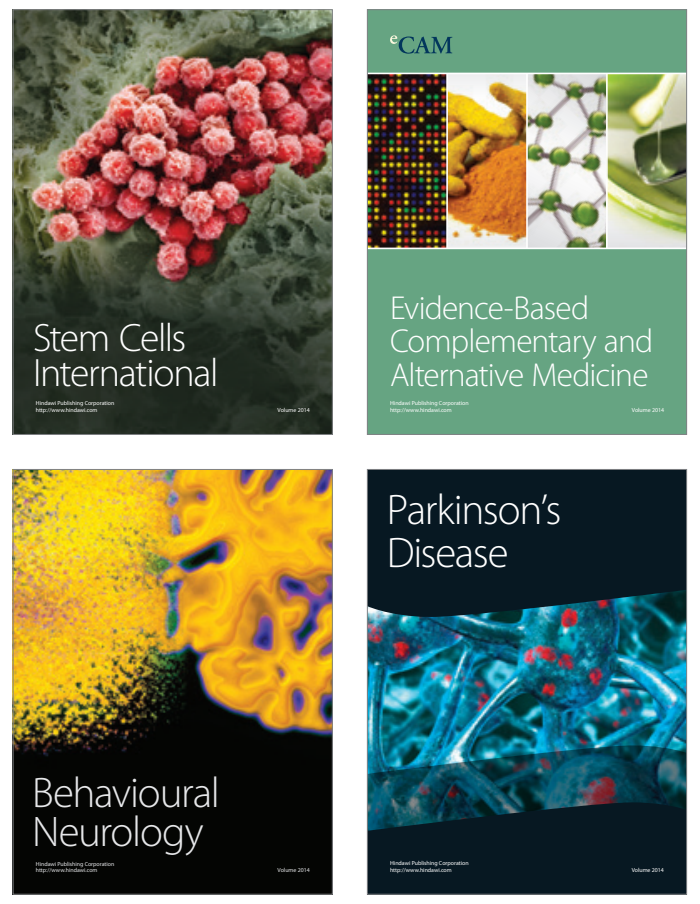
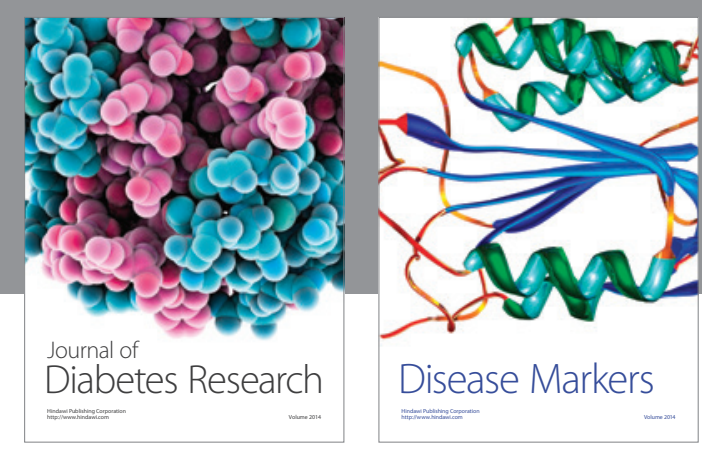

Disease Markers
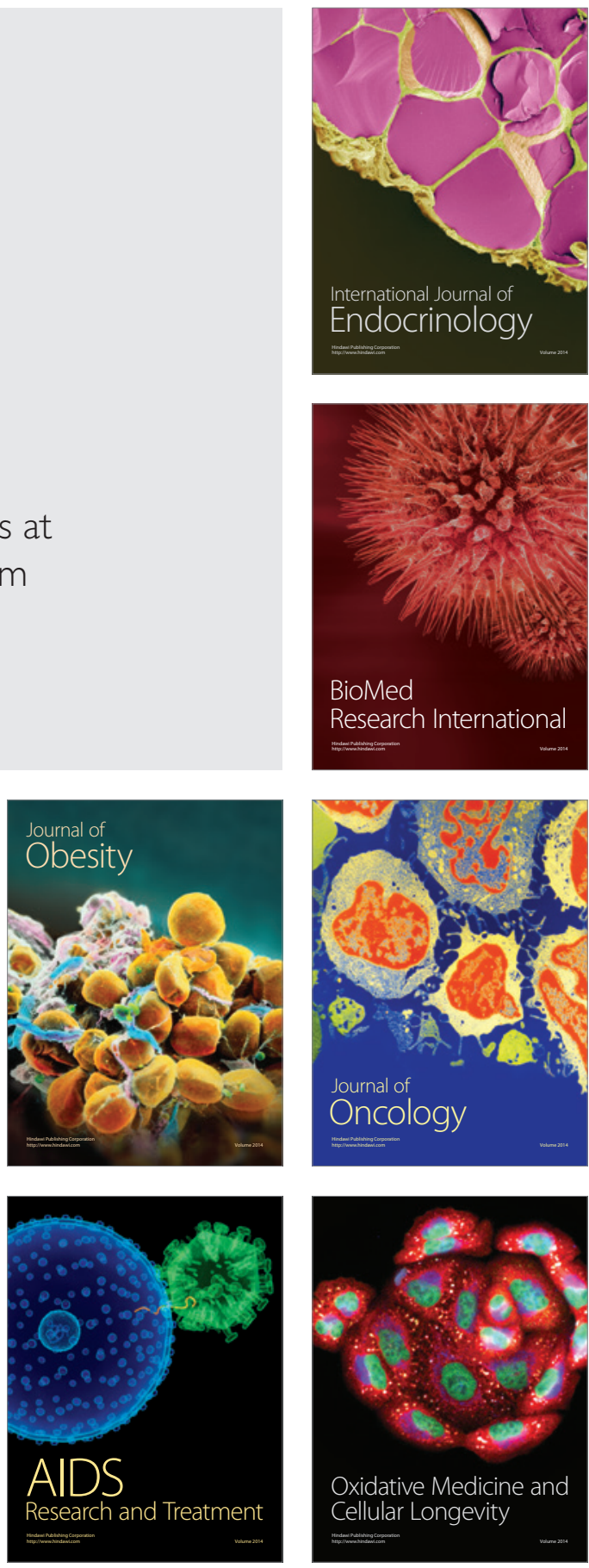